\title{
SOCIO-ECONOMIC CONDITION OF GAMELAN CRAFTER IN WIRUN VILLAGE MOJOLABAN SUBDISTRICT SUKOHARJO DISTRICT 2019
}

\author{
Greti Regita Maharani ${ }^{1}$, Agus Sudargono ${ }^{2}$, Muh Husyain Rifai ${ }^{3}$ \\ 1,2,3 Geography Education, Universitas Veteran Bangun Nusantara \\ Email: ${ }^{1}$ regitagreti@gmail.com
}

\begin{abstract}
This study aims to find out: (1) The Socio-Economic Condition of Gamelan Craftsmen in Wirun Village, Mojolaban District, Sukoharjo Regency. (2) Level of Education of Gamelan Craftsmen in Wirun Village, Mojolaban Subdistrict, Sukoharjo Regency. (3) Distribution of Gamelan Home Industries and Gamelan Marketing Range in Wirun Village, Mojolaban District, Sukoharjo District.

This study used qualitative descriptive, namely describing and knowing the socio-economic conditions of gamelan craftsmen in Wirun Village, the level of education of gamelan craftsmen in Wirun Village and knowing the distribution of the gamelan industry in Wirun Village and also the marketing range of the gamelan industry. The data collection techniques used are through field direct observation, interviews and documentation. Data analysis techniques used are analysis of descriptive data and table data.

The results of this study are: (1) the socio-economic conditions of gamelan craftsmen totaling 26 craftsmen of all ages 15-64 years, the highest level of education is high school, the income level of 20 craftsmen ranges from 1,920,000-2,400,000, the number of family dependents is dominated by 3-5 people, the gamelan industry stands on average 10-50 years (2) The results of the highest education level of children at the level of high school / vocational and craftsman children are predominantly female. (3) The results of the spread of the gamelan industry are 6 industries and the majority of marketing reach the island of Bali.
\end{abstract}

Keywords: distribution, gamelan, craftsmen

\section{A. INTRODUCTION}

The development of village is a development strategic to improve the socio-economic condition of rural inhabitants. This development has purpose to reduce the poverty level that makes this program has to be clear and directed designed. The rural development is close to the physical and non-agricultural development such as small-scale and household industry. These industries are potentially able to solve the basic problem of development in Indonesia to achieve the national economic growth. It also has influence to create a sustainable industrial process.

Home industry is considered as a small-scale household industry. According to Law Number 99 Year 1995, home industry is a small-scale economic activity that fulfills net worth criteria or annual selling outcome and ownership as regulated in the national law. Home industry 
takes its part in labour and job vacancy. It is because home industry is labor intensive since it needs large workforce both adults and adolescents whose special espertise. Those labors are usually coming from the surrounding areas or families.

Wirun village in Mojolaban Subdistrict is one of villages in Sukoharjo District in which the inhabitants are Gamelan crafters who have been well-known internationally and still preserve the gamelan making process. Gamelan craft in Wirun village has been established since 1956 with the economic factor was becoming the main driver since this village has abundant agricultural products.

Therefore, this study is conducted to know the socio-economic condition of Gamelan crafters in Wirun village by looking the education level of Gamelan crafter's children as well as to know the distribution of Gamelan home industry with its market reach.

\section{B. METHODS}

This research used descriptive qualitative method which is a research procedure that produces descriptive data in written and oral words from people and observable behaviour (Bogdan and Taylor in Moloeng, 2012). This method is used to describe the socioeconomic condition of Gamelan crafters and the market reach of Gamelan home industry. Beside describing those condition, this study also describes the distribution of Gamelan home industry that is obtained by mean of plotting the location of Gamelan industry that later will be depicted in a map.

The data used in this study is primary and secondary data. The primary data is the coordinate location of Gamelan industry and direct interview with Gamelan crafters of Wirun village, Mojolaban sub district, Sukoharjo district. While the secondary data is document and literature that are related to the distribution of crafters, socioeconomic condition, and the market reach of Gamelan industry in the form of book, research, government law, and Indonesian Topographical Map (RBI) as the base map.

\section{RESULT}

Wirun village is located in Mojolaban Sub district Sukoharjo District 125 meters above sea level. This village is situated in a slope of $5-15 \%$ and the rainfall intensity is $1500-2000 \mathrm{~mm}$. The distance of this village to the district center is about $10 \mathrm{~km}$ in 25 minutes while the distance to the sub district center is about $0,7 \mathrm{~km}$ in 10 minutes.

This study aims to determine the socioeconomic condition of Gamelan craftsmen in Wirun village, the level of their children's education, as well as the distribution and the market range 
of Gamelan industry. The village itself has been famous as a gamelan producing village that is still exist today. The data was obtained from 6 gamelan industry owners in Wirun village as well as from gamelan artisans, related agencies, observations, and documentations while 20 labors were taken as the sample of gamelan indusrty workers.

The result which contains the socioeconomic condition of the owners and craftsmen including age level, gender, education level, heatlh insurance, income level, family dependency and length of business will be tabulated. Data was obtained from the interview with selected respondents which are the business owners and labors that can be seen in tables below.

Table 1. List of Respondents

\begin{tabular}{|c|c|c|c|}
\hline $\begin{array}{l}\text { No } \\
(1)\end{array}$ & $\begin{array}{l}\text { Name } \\
(2)\end{array}$ & $\begin{array}{c}\text { Address } \\
(3)\end{array}$ & $\begin{array}{c}\text { Workplace } \\
(4)\end{array}$ \\
\hline 1 & Sarijo & Karangplumbon Sukoharjo & UD.Werdhi Gongso \\
\hline 2 & Bambang Edi S & Demakan RT 03/08 Skh & UD. Werdhi Gongso \\
\hline 3 & Sumardi & Bakalan Polokarto & UD. Werdhi Gongso \\
\hline 4 & Wahyudi & Kalangan Polokarto & UD.Werdhi Gongso \\
\hline 5. & Sutarno & Wirun RT 1 & UD. Werdhi Gongso \\
\hline 6. & Budi Utomo & Wirun Mojolaban & UD. Laras Jowo Aji \\
\hline 7. & Sardi & Tudungan Mojolaban & UD. Laras Jowo Aji \\
\hline 8. & Sukamto & Wirun Mojolaban & UD. Laras Jowo Aji \\
\hline 9. & Budiyono & Gendengan RT 4 & UD. Laras Jowo Aji \\
\hline 10. & Supoyo & Mertan RT 1 & UD.Supoyo \\
\hline 11. & Suwardi & Wirun Mojolaban & UD. Supoyo \\
\hline 12. & Mulyadi & Jogopaten Gentan Bendosari & UD. Supoyo \\
\hline 13. & Sumardi & Godean Wirun & UD. Supoyo \\
\hline 14. & Sanjoyo & Wirun RT02 & Panji Gong Agung \\
\hline 15. & Agus & Wirun RT01/RW05 & Panji Gong Agung \\
\hline 16. & Beni & Tegalmade Mojolaban & Panji Gong Agung \\
\hline 17. & Mugino & Wirun RT01/RW05 & Panji Gong Agung \\
\hline 18. & Mulyadi & Wirun RT01/RW05 & Panji Gong Agung \\
\hline 19. & Warjono & Gendengan RT4/RW4 & Panji Gong Agung \\
\hline 20. & Sugeng Setyono & Wirun RT 3 & UD. Aji Gongso \\
\hline
\end{tabular}




\begin{tabular}{|c|l|l|l|}
\hline $\begin{array}{c}\text { No } \\
(1)\end{array}$ & \multicolumn{1}{|c|}{$\begin{array}{c}\text { Name } \\
(2)\end{array}$} & \multicolumn{1}{|c|}{$\begin{array}{c}\text { Address } \\
(3)\end{array}$} & \multicolumn{1}{c|}{$\begin{array}{c}\text { Workplace } \\
(4)\end{array}$} \\
\hline 21. & Aji & Tohkuning Karangpandan & UD. Aji Gongso \\
\hline 22. & Suparno & Tohkuning RT3/RW XI & UD. Aji Gongso \\
\hline 23. & Wahyu Wiranto & Tohkuning Karangpandan & UD. Aji Gongso \\
\hline 24. & Jumadi & Krajan RT 4/RW6 Laban & UD. Palu Gongso \\
\hline 25. & Kasdi & Sembung RT01/RW11 & UD. Palu Gongso \\
\hline 26. & Suroyo & Gendengan RT 4 & UD. Palu Gongso \\
\hline
\end{tabular}

Table 2. Craftsmen Age Group

\begin{tabular}{|c|c|c|}
\hline No & Age Group & Total (people) \\
\hline 1 & $0-14$ tahun & - \\
\hline 2 & $15-64$ tahun & 26 \\
\hline 3 & $>65$ tahun & - \\
\hline & Jumlah & 26 \\
\hline
\end{tabular}

Table 3. Craftsmen Education Level

\begin{tabular}{|c|l|c|}
\hline No & Education Level & Total (people) \\
\hline 1 & Elementary School & 8 \\
\hline 2 & Junior High School & 11 \\
\hline 3 & Senior High School & 7 \\
\hline 4 & Bachelor Degree & - \\
\hline 5 & Not Graduated & - \\
\hline \multicolumn{2}{|c|}{ Jumlah } & 26 \\
\hline
\end{tabular}

From the above data it can be said that the level of education of gamelan craftsmen in Wirun Village is still low in which it is still dominated by the elementary graduates of 8 people and junior high school of 11 people while only 7 people are graduated from high school.

Table 4. The Income Level of Craftsmen

\begin{tabular}{|l|l|c|}
\hline No & \multicolumn{1}{|c|}{ Income } & Total (people) \\
\hline 1 & Rp. 1.920 .000 & 8 \\
\hline 2 & Rp. 2.160 .000 & 6 \\
\hline 3 & Rp. 2.400 .000 & 6 \\
\hline & Jumlah & 20 \\
\hline
\end{tabular}


From above data, it can be seen that the income of craftsmen is in accordance with the minimum wage of Sukoharjo Regency, even higher. 8 respondents have income Rp. 1.920.000/month, 6 respondents have income Rp. 2,160,000/month and 6 respondents have salary $\mathrm{Rp} 2,400,000 /$ month with 6 day working a week. It is the net salary since each industry provides food for the workers.

While the education level of the crafters' kids are categorized into two groups which are the group of schooling students and the group of graduated students. Afterwards, the school participation rates to see the proportion of children who are still studying at the certain age is determined (Figure 1).

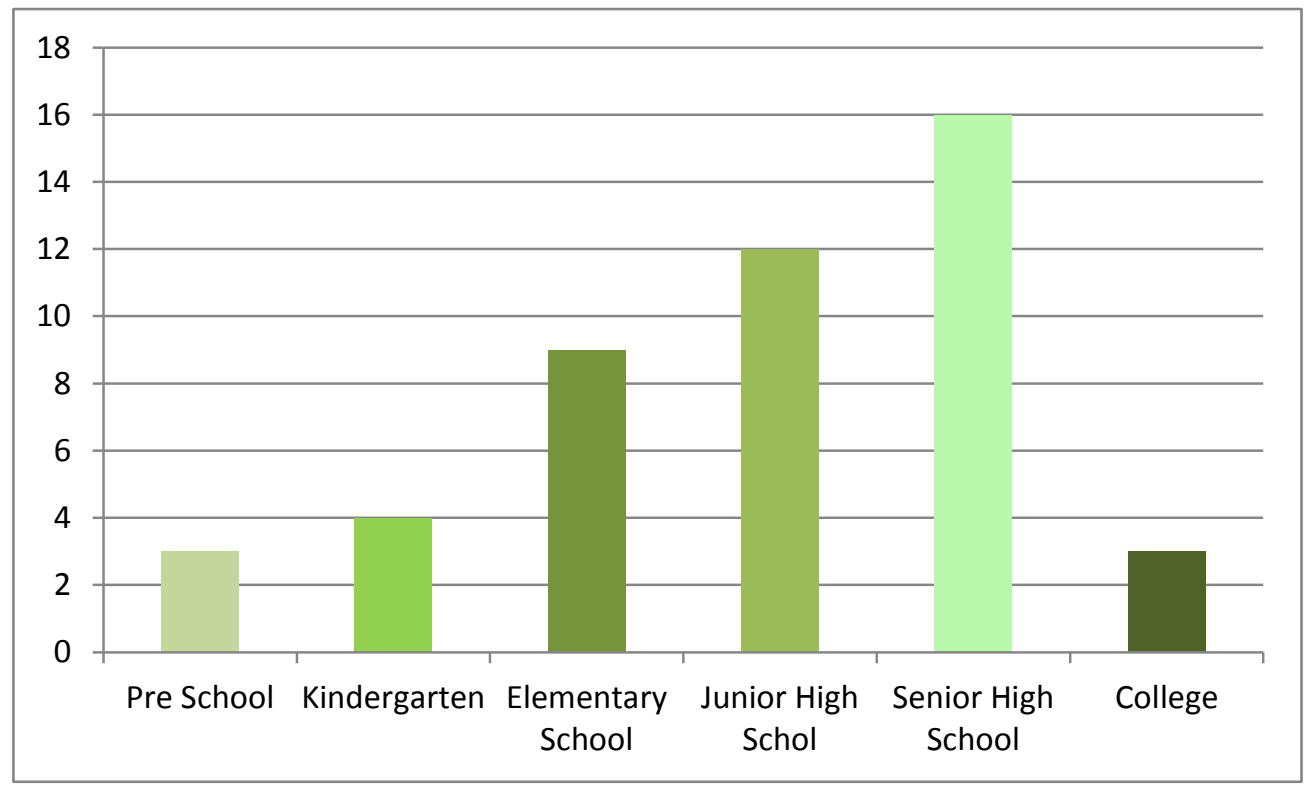

Figure 1. The education level of Gamelan Craftmens' children

From the figure, it can be seen that there are 3 childre at pre-school education, 4 children at kindergarten, 9 children at elementary school, 12 youngster at junior high school, 16 juvenils at high school and 3 youths at college education. Therefore, the education level of crafters' children is dominated by senior high school level (Figure 1), and the majority of them are woman (Figure 2). 


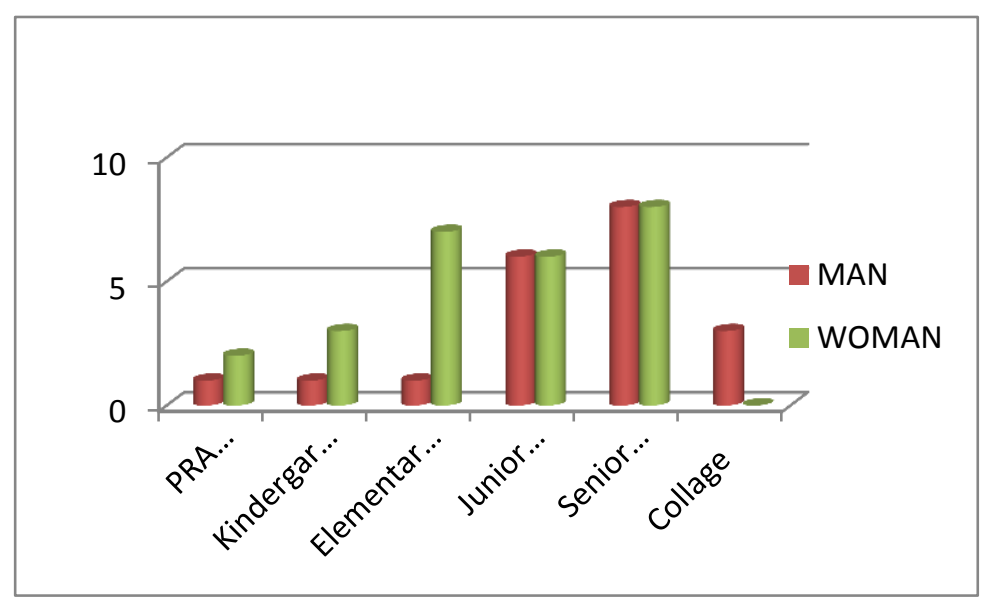

Figure 2. The education level based on gender

Wirun Village is the sole location of gamelan industry in Sukoharjo regency and has been famous as the center of gamelan production since a long time ago. The distribution of gamelan industy is uneven since it is only spread over a number of hamlets. As the time goes by, the development of gamelan is not as popular as before because it has no regeneration of the gamelan craftsmen, therefore there are only 6 gamelan crafters nowadays who still actively produce gamelan. The production is marketed both dosmetic and abroad. The majority of domestic marketing covers the areas of Bali, Jogjakarta, Jakarta, and Wonogiri.

\section{CONCLUSION}

The socio-economic condition of Gamelan craftsmen in Wirun village based on age level is categorized in productive age to work. From the education level, averagely the craftsmen were graduated from elementary school and junior high school while from the income level mostly their salary has exceeded the minimum wage of Sukoharjo regency with daily income around Rp. 80.000 - Rp. 100.000. Related to their children, there are 3 todlers who study in preschool, 4 kids in kindergarten, 9 children in elementary shool, 12 students in junior high school, and 16 juvenils in senior high school, and 3 students in college. Finally, there are 6 industries of Gamelan in Wirun village with the major market in Bali.

\section{E. REFERENCE}

Ananta,Dimas Bagus "Pengaruh Keberadaan Industri Sirup Jeruk Nipis Peras Terhadap Kondisi Sosial Ekonomi Masyarakat Desa Ciawigebang Kecamatan Ciawigebang Kabupaten Kuningan,' 'Skripsi pada universitas Pendidikan Indonesia Bandung,2014 
Damsar dan Indrayani. 2009. Pengantar Sosiologi Ekonomi. Jakarta: PRENADAMEDIA GROUP

Departemen Pendidikan Nasional Undang-Undang RI tahun 2010 tentang sistem Tingkat Pendidikan

Kiefer, and Lillesand. 1990. Penginderaan Jauh dan Interpretasi Citra. Jogjakarta: UGM Press.

Marfai, Aris. 2015. Pemodelan Geografi. Yogyakarta : Ombak

Minda Rafiani (2018) Jangkauan Pemasaran Home Industri Intip Desa Jati Kecamatan Sumberlawang Kabupaten Sragen.

Moleong, Lexy. J. 2007. Metode Penelitian Kualitatif. Bandung: Rosda Karya

Muhimatun Afidah (2014) Kehidupan Sosial Ekonomi Penduduk Pembuat Batubata Di Desa Rejosari Kecamatan Brangsong Kabupaten Kendal .

Pasal 1 UU.RI No 20 tahun 2003 tentang sistem pendidikan nasional Republik Indonesia tahun 1989. Undang - undang Nomor 2 Tahun1989 tentang tingkat pendidikan Lembaran Negara RI Tahun 1989, dibuat di Jakarta.

Republik Indonesia tanggal 29 juni 1984. Undang - undang Nomor 5 Tahun 84 tentang perindustrian oleh Presiden. Lembaran Negara RI Tahun 1984, dibuat di Jakarta

Soekanto, Soerjono dan Budi Sulistyowati. 2015. Sosiologi Suatu Pengantar. Jakarta: RajaGrafindo Persada

Sugiyono, 2008. Metode Penelitian Kuantitatif, Kualitatif dan R\&D. Bandung : Penerbit Alfabet

Sutanto, 1994. Penginderaan Jauh dan Interpretasi Citra Jilid 1, cetakan III. Jogjakarta: UGM Press.

Sutanto, 1994. Penginderaan Jauh dan Interpretasi Citra Jilid 2, cetakan III. Jogjakarta :UGM Press

Tika, Moh. Pabundu.2005. Metode Penelitian Geografi. Jakarta: Gramedia Pustaka Utama 